\title{
Immunological Enhancement of Interferon Alpha Treatment to Allogeneic Bone Marrow Transplantation in Irradiated Rats
}

\author{
E. M. Hussein and Y. H. Abd El-Naby* \\ Radiation Biology Dept., National Centre for Radiation \\ Research Technology (NSRRT), P. O. Box; 29 Nasr City, Egypt \\ and ${ }^{*}$ Zoology Dept., Faculty of Science, Al-Azhar University \\ for Girls.
}

\footnotetext{
THE INFLUENCE of the biological response modifiers: interferon alpha (IFN- $\alpha$ ) and bone marrow transplantation (BMT) on stimulation of blood cell recovery and boosting the immunological response were investigated in this work. Male rats received BMT $3 \mathrm{~h}$ post total body $\gamma$-irradiation of $5 \mathrm{~Gy}$ and were injected with 10 units of IFN- $\alpha$ weekly for 5 weeks.

Irradiation induced a significant decrease in blood parameters, reduced glutathione (GSH) as well as bone marrow lymphocyte count and viability. Immunological data revealed that tumour necrosis factor alpha (TNF- $\alpha$ ) and interleukin-2 (IL-2) recorded a significant depression while lipid peroxidation (MDA) was conversely elevated. White blood cells (WBC), erythrocytes (RBC), haemoglobin $(\mathrm{Hb})$, haematocrit (Hct), lymphocytes and GSH in irradiated animals receiving BMT and IFN- $\alpha$, were significantly elevated, while MDA was significantly depressed as compared to the irradiated group. Bone marrow lymphocytic count and viability percentage were significantly increased while IL-2 and TNF- $\alpha$ were normalized.

The curative action of IFN- $\alpha$ enforcing significant innate response could trigger and augment adaptive immune response by bone marrow transplantation. Such therapies boosting both components of immunity would be considered a potential strategy for irradiation treatment.

Keywords: Bone marrow, interferon alpha, $\gamma$-rays, rats.
}

Most of cellular alterations induced by ionizing radiation is indirect and is mediated by the generation of free radicals and related reactive species, mainly derived from oxygen (Maurya et al., 2007). Acute effects of radiation include hematopoietic cell loss, immune suppression and potential injury to other sites (Augestin et al., 2005). 
Adult bone marrow (BM) contains cells that can differentiate into mature, non-haematopoietic cells of multiple tissues including cells of the kidney, lung, liver, skin, gastrointestinal tract and fibres of heart and skeletal muscle (Abedi et al., 2004). Infusion of haematopoietic stem cell can be done from a donor into a patient who has received chemotherapy or irradiation dose that can be marrow ablative (Bonadio et al., 2005). Irradiation of mice followed by transplantation of stem cells of the immune system became a much-used method that fostered the burgeoning field of cellular immunology.

IFN- $\alpha$ is a glycoprotein produced by B-lymphocytes of peripheral blood. It has antiviral and antiproliferative activity and hence anti-tumour effect. It has modulating effects on immunological system. Survival time of lethally irradiated mice can be significantly extended if exogenous IFN- $\alpha$ or IFN- $\alpha$ inducers are administrated post-irradiation (Ortaldo and McCoy, 1980). In Chernobyl patients, regulatory administrated IFN- $\gamma$ proved to be a successful therapeutic option for radiation fibrosis, with little side effects (Peter et al., 1999). IFN- $\alpha$ therapy of haematological relapse after BMT is generally well tolerated and produces durable complete cytogenetic responses (Higano et al., 1997). Lu et al. (2002) speculate that IFN- $\alpha$ enhances biological defence activities against oxidative stress and functions as a potent antifibrotic by protecting hepatocytes from lipid peroxidation in-vivo.

This work aims to investigate if boosting of adaptive and innate immunity by bone marrow cells and IFN- $\alpha$ injection could affect blood reconstitution and could minimize irradiation induced oxidative stress.

\section{Material and Methods}

108 mature male albino rats of pure strain (110-150 g) were obtained from the animal house of the NCRRT, Nasr City, Egypt. Rats were kept under good ventilation conditions, allowed free access to water and rat diet.

Irradiation facility: Whole body irradiation was performed by Gamma-cell $40\left({ }^{137} \mathrm{Cesium}\right)$ belonging to NCRRT. Animals were irradiated at an acute single dose of $5 \mathrm{~Gy}$ at a dose rate of $0.44 \mathrm{~Gy} / \mathrm{min}$.

\section{Interferon- $\alpha$ treatment}

IFN- $\alpha$ is prepared from culture of genetically modified Escherichia coli Egypt. J. Rad. Sci. Applic., Vol. 25, No. 1-2 (2012) 
using recombinant DNA technology; each vial contains 3 million IU. Rats were injected subcutaneously (s.c.) with 10 units of IFN- $\alpha$ once a week for 5 weeks (Muriel and Castro, 1997).

\section{Bone marrow transplantation}

Donors and recipients were chosen of the same inbred strain, brother to brother (allogeneic transplantation). Femur bones were dissected out, cleaned, and the marrow was blown out into isotonic solution under sterilized conditions and mixed by drawing and expelling it several times from the syringe without needle to avoid mechanical damage. Total viable cells of about $75 \times 10^{6} \pm 5 \%$ were injected intravenously (i.v.) $3 \mathrm{~h}$ after irradiation (Decleave et al., 1972).

\section{Animal groups}

Rats were sorted into 7 groups: 1-Control rats (C). 2-Rats received BMT cells $\left(75 \times 10^{6}\right)$ through the caudal vein $\left(\mathrm{C}_{\mathrm{BM}}\right)$. 3-Rats injected subcutaneously with 10 units of IFN- $\alpha\left(\mathrm{C}_{\mathrm{IFN}-\alpha}\right)$. 4-Animals exposed to $5 \mathrm{~Gy}$ whole body gamma irradiation (R). 5-Group of rats exposed to $5 \mathrm{~Gy}$ gamma irradiation and received $\mathrm{BM}$ cells $3 \mathrm{~h}$ post irradiation ( $\mathrm{R}+\mathrm{BM})$. 6-Animals exposed to 5Gy gamma irradiation and injected s.c. with 10 units of IFN- $\alpha(\mathrm{R}+\mathrm{IFN}-\alpha)$. 7-Group of rats exposed to 5Gy gamma irradiation and treated with BM cells $3 \mathrm{~h}$ after irradiation and injected with 10 units of IFN- $\alpha(\mathrm{R}+\mathrm{BM}+\mathrm{IFN}-\alpha)$. All animals groups were sacrificed after 5 weeks.

Groups of 9 rats were slightly anaesthetized and blood was collected by heart puncture. Part of the blood was mixed with EDTA to determine RBCs and WBCs using a haemocytometer while differential leukocyte count and Hct\% were performed according to Dacie and Lewis (1993). Blood Hb content was assayed using Spectrum Diagnostic kit according to Carl and Braun (2005) and reduced GSH content was measured according to Beutler et al. (1963). The rest of the blood was centrifuged to obtain serum. MDA was determined according to Yoshioka et al. (1979). IL-2 and TNF- $\alpha$ concentrations were determined using ELIZA kits according to Chan and Perlstein, (1987) and Aramachi (1989), respectively. Determination of viable bone marrow count was performed according to Esser et al. (2001) and bone marrow lymphocyte count according to Sinai et al. (1978). 


\section{Statistical analysis}

The results are expressed as mean \pm S.E. Data were analyzed using one way analysis of variance (ANOVA) followed by Duncan's test (1957). Differences were considered significant at $P$-value $\leq 0.05$.

\section{Results}

Results revealed significant $(P<0.05)$ decrease in blood parameters after 5 weeks by BMT alone, whereas IFN- $\alpha$ injection alone showed significant decrease of $\mathrm{Hb}$ content and WBCs compared to control. Irradiation at $5 \mathrm{~Gy}$ induced significant depression in all studied blood parameters. Irradiation combined with BMT or IFN- $\alpha$ treatment showed a significant elevation in Hct, $\mathrm{Hb}, \mathrm{RBCs}$ and WBCs compared to irradiated group. BMT combined with IFN- $\alpha$ and irradiation normalized blood parameters, Table 1.

TABLE 1. Effect of BMT and IFN- $\alpha$ administration on blood parameters in irradiated and non-irradiated rats.

\begin{tabular}{|c|c|c|c|c|}
\hline Group & $\begin{array}{c}\text { WBCs } \\
10^{3} / \mathrm{mm}^{3}\end{array}$ & $\begin{array}{c}\text { RBCs } \\
10^{6} / \mathrm{mm}^{3}\end{array}$ & $\begin{array}{l}\mathbf{H b} \\
\mathrm{g} / \mathrm{dl}\end{array}$ & $\begin{array}{c}\text { Het } \\
\%\end{array}$ \\
\hline Control & $6.1 \pm 2.15$ & $14.6 \pm 0.46$ & $14.8 \pm 0.36$ & $43.9 \pm 1.40$ \\
\hline $\mathbf{C}_{\text {BMT }}$ & $\begin{array}{c}5.7 \pm 1.47 \\
\mathrm{c}\end{array}$ & $\begin{array}{c}12.5 \pm 0.45 \\
\mathrm{c}\end{array}$ & $\begin{array}{c}11.4 \pm 0.57 \\
\mathrm{c}\end{array}$ & $\begin{array}{c}37.5 \pm 1.36 \\
\mathrm{c}\end{array}$ \\
\hline $\mathrm{C}_{\text {IFN- } \boldsymbol{\alpha}}$ & $\begin{array}{c}5.5 \pm 2.13 \\
c\end{array}$ & $\begin{array}{c}11.3 \pm 0.40 \\
\mathrm{c}\end{array}$ & $\begin{array}{c}11.3 \pm 0.40 \\
\mathrm{c}\end{array}$ & $41.9 \pm 1.87$ \\
\hline $\mathbf{R}$ & $\begin{array}{c}2.5 \pm 1.71 \\
\mathrm{c}\end{array}$ & $\begin{array}{c}8.2 \pm 0.25 \\
c\end{array}$ & $\begin{array}{c}8.2 \pm 0.25 \\
c\end{array}$ & $\begin{array}{c}28.5 \pm 0.79 \\
\mathrm{c}\end{array}$ \\
\hline R+ BMT & $\begin{array}{c}5.2 \pm 2.18 \\
c\end{array}$ & $\begin{array}{c}9.4 \pm 0.13 \\
c\end{array}$ & $\begin{array}{c}9.4 \pm 0.13 \\
c\end{array}$ & $\begin{array}{c}33.4 \pm 1.36 \\
\mathrm{c}\end{array}$ \\
\hline R+ IFN- $\alpha$ & $\begin{array}{c}3.9 \pm 1.3 \\
\mathrm{cr}\end{array}$ & $\begin{array}{c}9.2 \pm 0.14 \\
\mathrm{c} \mathrm{r}\end{array}$ & $\begin{array}{c}9.2 \pm 0.14 \\
\mathrm{c} \mathrm{r}\end{array}$ & $\begin{array}{c}39.2 \pm 2.92 \\
\mathrm{r}\end{array}$ \\
\hline $\mathrm{R}+\mathrm{BMT}+\mathrm{IFN}-\alpha$ & $\begin{array}{c}6.1 \pm 2.15 \\
\mathrm{r}\end{array}$ & $\begin{array}{c}14.0 \pm 0.36 \\
\mathrm{r}\end{array}$ & $\begin{array}{c}14.0 \pm 0.36 \\
\mathrm{r}\end{array}$ & $\begin{array}{c}41.8 \pm 1.78 \\
\mathrm{r}\end{array}$ \\
\hline
\end{tabular}

Values are expressed as mean \pm S.E., ANOVA test.

c: Significant difference compared to control. r: Significant difference compared to R group.

Results in Table 2. demonstrated that BMT alone and IFN- $\alpha$ alone showed no change in differential leucocytes as compared to control. Significant $(P<$ 0.05 ) reductions were recorded in lymphocytes, monocytes and neutrophils, while eosinophils and basophils were significantly increased 5 weeks post 5Gy $\gamma$-irradiation. BMT post irradiation induced a significant increase in 
lymphocytes and monocytes, a significant decrease in eosinophils and basophils compared to irradiated group whereas, neutrophils were significantly decreased compared to control. IFN- $\alpha$ treatment post irradiation showed significant increase in lymphocytes and monocytes compared to irradiated group. Dual treatments normalized monocytes, lymphocytes and neutrophil percentage while, eosinophils and basophils had a significant decrease compared to irradiated group.

TABLE 2. Effect of BMT and IFN- $\alpha$ administration on differential leukocyte in irradiated and non-irradiated rats.

\begin{tabular}{|c|c|c|c|c|c|}
\hline Group & $\begin{array}{c}\text { Lymphocyte } \\
\%\end{array}$ & $\begin{array}{c}\text { Monocyte } \\
\%\end{array}$ & $\begin{array}{c}\text { Neutrophil } \\
\%\end{array}$ & \begin{tabular}{|c|} 
Eosinophil \\
$\%$
\end{tabular} & $\begin{array}{c}\text { Basophil } \\
\%\end{array}$ \\
\hline Control & $31.6 \pm 1.01$ & $4.0 \pm 0.57$ & $59.8 \pm 1.47$ & $3.8 \pm 0.65$ & $0.7 \pm 0.21$ \\
\hline $\mathrm{C}_{\mathrm{BMT}}$ & $30.8 \pm 1.24$ & $4.7 \pm 0.33$ & $58.5 \pm 1.47$ & $4.7 \pm 0.42$ & $1.0 \pm 0.36$ \\
\hline $\mathrm{C}_{\text {IFN- } \alpha}$ & $30.5 \pm 3.52$ & $4.8 \pm 0.40$ & $1.74 \pm 60.2$ & $4.0 \pm 0.57$ & $0.8 \pm 0.30$ \\
\hline $\mathbf{R}$ & $\begin{array}{c}16.2 \pm 9.66 \\
\mathrm{c}\end{array}$ & $\begin{array}{c}1.8 \pm 0.47 \\
\mathrm{c}\end{array}$ & $\begin{array}{c}46.3 \pm 1.74 \\
\mathrm{c}\end{array}$ & $\begin{array}{c}25.8 \pm 1.74 \\
\mathrm{c}\end{array}$ & $\begin{array}{c}4.3 \pm 0.49 \\
\mathrm{c}\end{array}$ \\
\hline $\mathbf{R}+\mathbf{B M T}$ & $\begin{array}{c}19.6 \pm 1.43 \\
\text { c r }\end{array}$ & $\begin{array}{c}2.8 \pm 0.30 \\
r\end{array}$ & $\begin{array}{c}46.7 \pm 1.80 \\
\mathrm{c}\end{array}$ & \begin{tabular}{|c|}
$21.3 \pm 1.14$ \\
$\mathrm{c} \mathrm{r}$
\end{tabular} & $\begin{array}{c}3.2 \pm 0.30 \\
\mathrm{c} \mathrm{r}\end{array}$ \\
\hline R+ IFN- $\alpha$ & $\begin{array}{c}17.7 \pm 1.64 \\
\text { c r }\end{array}$ & $\begin{array}{c}2.3 \pm 0.61 \\
\mathrm{c} \mathrm{r}\end{array}$ & $\begin{array}{c}39.5 \pm 1.58 \\
\text { c r }\end{array}$ & $\begin{array}{c}29.0 \pm 1.77 \\
\mathrm{c}\end{array}$ & $\begin{array}{c}3.5 \pm 0.50 \\
\mathrm{c}\end{array}$ \\
\hline $\mathrm{R}+\mathrm{BMT}+\mathrm{IFN}-\alpha$ & $\begin{array}{c}29.3 \pm 2.78 \\
\mathrm{r}\end{array}$ & $\begin{array}{c}5.0 \pm 0.36 \\
\mathrm{r}\end{array}$ & $\begin{array}{c}61.2 \pm 1.95 \\
\mathrm{r}\end{array}$ & $\begin{array}{c}12.0 \pm 1.06 \\
\mathrm{c} \mathrm{r}\end{array}$ & $\begin{array}{c}1.8 \pm 0.30 \\
\mathrm{c} \mathrm{r}\end{array}$ \\
\hline
\end{tabular}

Legend as in Table 1.

TABLE 3. Effect of BMT and IFN- $\alpha$ administration on BM lymphocyte and viable BM counts in irradiated and non-irradiated rats.

\begin{tabular}{|c|c|c|}
\hline Groups & $\begin{array}{c}\text { BM lymphocyte count } \\
\%\end{array}$ & $\begin{array}{c}\text { Viable bone marrow count } \\
\%\end{array}$ \\
\hline Control & $21.2 \pm 1.07$ & $67.4 \pm 1.19$ \\
\hline $\mathrm{C}_{\text {BMT }}$ & $22.3 \pm 0.71$ & $69.8 \pm 0.70$ \\
\hline $\mathrm{C}_{\mathrm{IFN}-\alpha}$ & $19.7 \pm 0.66$ & $\begin{array}{c}63.3 \pm 0.61 \\
\mathrm{c}\end{array}$ \\
\hline $\mathbf{R}$ & $\begin{array}{c}12.5 \pm 0.76 \\
\mathrm{c}\end{array}$ & $\begin{array}{c}41.7 \pm 1.74 \\
\mathrm{c}\end{array}$ \\
\hline R+ BMT & $\begin{array}{c}16.2 \pm 0.60 \\
\mathrm{c}\end{array}$ & $\begin{array}{l}50.9 \pm 1.49 \\
\text { c r }\end{array}$ \\
\hline R+ IFN- $\alpha$ & $\begin{array}{c}13.3 \pm 0.80 \\
\mathrm{c}\end{array}$ & $\begin{array}{c}45.2 \pm 1.33 \\
\mathrm{c}\end{array}$ \\
\hline $\mathrm{R}+\mathrm{BMT}+\mathrm{IFN}-\alpha$ & $\begin{array}{c}21.2 \pm 0.47 \\
\mathrm{r}\end{array}$ & $\begin{array}{l}62.1 \pm 1.57 \\
\quad \text { c r }\end{array}$ \\
\hline
\end{tabular}

Legend as in Table 1 .

Egypt. J. Rad. Sci. Applic., Vol. 25, No. 1-2 (2012) 
BMT showed no significant difference of bone marrow lymphocyte count and viability while IFN- $\alpha$ induced a significant reduction of viable lymphocyte viability $(P<0.05)$. Exposure to $\gamma$-radiation induced a significant reduction in bone marrow lymphocytes and viability. Only BMT after irradiation recorded a significant increase in viable BM lymphocyte count compared to irradiated group, while IFN- $\alpha$ did not show any change. Dual treatments elevated these values compared to irradiated group.

BMT or IFN- $\alpha$ alone showed a significant $(P<0.05)$ increase in IL-2 as compared to control group while, TNF- $\alpha$ showed no change. A significant decrease was obtained in serum IL- 2 and TNF- $\alpha$ post $\gamma$-irradiation. BMT post irradiation exerted no significant change in IL-2 while, TNF- $\alpha$ had a significant elevation compared to the irradiated group. IFN- $\alpha$ post irradiation showed a significant increase in both parameters compared to irradiated group while, dual treatment normalized IL-2 and TNF- $\alpha$, Table 4.

TABLE 4. Effect of BMT and IFN- $\alpha$ administration on IL-2 and TNF- $\alpha$ in irradiated and non-irradiated rats.

\begin{tabular}{|c|c|c|}
\hline Groups & $\begin{array}{c}\text { IL-2 } \\
\mathrm{pg} / \mathrm{ml}\end{array}$ & $\begin{array}{l}\text { TNF- } \alpha \\
\text { pg/ ml }\end{array}$ \\
\hline Control & $165.2 \pm 6.72$ & $353.4 \pm 18.07$ \\
\hline $\mathrm{C}_{\mathrm{BMT}}$ & $\begin{array}{c}192.5 \pm 7.05 \\
\mathrm{c}\end{array}$ & $345.1 \pm 3.27$ \\
\hline $\mathrm{C}_{\text {IFN- } \alpha}$ & $\begin{array}{c}208.5 \pm 8.42 \\
c\end{array}$ & $379.2 \pm 7.99$ \\
\hline $\mathbf{R}$ & $\begin{array}{c}117.6 \pm 7.63 \\
c\end{array}$ & $\begin{array}{c}185.1 \pm 10.82 \\
\mathrm{c}\end{array}$ \\
\hline $\mathrm{R}+\mathrm{BMT}$ & $\begin{array}{c}110.3 \pm 8.71 \\
\mathrm{c}\end{array}$ & $\begin{array}{c}251.3 \pm 6.55 \\
\mathrm{c} \mathrm{r}\end{array}$ \\
\hline R+ IFN- $\alpha$ & $\begin{array}{c}142.4 \pm 5.71 \\
\text { c r }\end{array}$ & $\begin{array}{c}327.5 \pm 6.39 \\
\mathrm{r}\end{array}$ \\
\hline $\mathrm{R}+\mathrm{BMT}+\mathrm{IFN}-\alpha$ & $\begin{array}{c}160.4 \pm 6.44 \\
\text { r }\end{array}$ & $\begin{array}{c}327.0 \pm 3.50 \\
\mathrm{r}\end{array}$ \\
\hline
\end{tabular}

Legend as in Table 1.

Results presented in Table 5 showed that BMT or IFN- $\alpha$ alone induced no change in GSH and MDA. A significant $(P<0.05)$ decrease was shown in GSH and a significant increase in serum MDA, post irradiation. BMT or IFN- $\alpha$ post irradiation significantly elevated GSH and decreased MDA compared to the irradiated group. Dual treatments normalized GSH.

Egypt. J. Rad. Sci. Applic., Vol. 25, No. 1-2 (2012) 
TABLE 5. Effect of BMT and IFN- $\alpha$ administration on blood GSH and serum MDA in irradiated and non-irradiated rats.

\begin{tabular}{|c|c|c|}
\hline Groups & $\begin{array}{c}\text { MDA } \\
\mu \mathrm{mol} / \mathrm{ml}\end{array}$ & $\begin{array}{c}\text { GSH } \\
\mathrm{mg} / \mathrm{ml}\end{array}$ \\
\hline Control & $38.71 \pm 0.64$ & $30.88 \pm 2.02$ \\
\hline $\mathrm{C}_{\text {BMT }}$ & $40.07 \pm 0.24$ & $28.55 \pm 0.59$ \\
\hline $\mathrm{C}_{\text {IFN- }-a}$ & $62.88 \pm 0.75 c$ & $28.47 \pm 1.19$ \\
\hline $\mathbf{R}$ & $\begin{array}{c}62.88 \pm 0.75 \\
\mathrm{c}\end{array}$ & $9.80 \pm 0.51 \mathrm{c}$ \\
\hline R+ BMT & $\begin{array}{c}47.05 \pm 0.92 \\
\text { c r }\end{array}$ & $\begin{array}{c}14.23 \pm 1.15 \\
\mathrm{c} \mathrm{r}\end{array}$ \\
\hline $\mathrm{R}+\mathrm{IFN}-\alpha$ & $\begin{array}{c}47.05 \pm 0.92 \\
\text { c r }\end{array}$ & $\begin{array}{c}14.10 \pm 0.49 \\
\mathrm{c} \mathrm{r}\end{array}$ \\
\hline $\mathrm{R}+\mathrm{BMT}+\mathrm{IFN}-\alpha$ & $\begin{array}{c}42.32 \pm 0.41 \\
\text { c r }\end{array}$ & $\begin{array}{c}28.22 \pm 0.76 \\
\mathrm{r}\end{array}$ \\
\hline
\end{tabular}

Legend as in Table 1

\section{Discussion}

Proliferation of stromal cells and bone-marrow stromal layer formation from stromal cells are sensitive to radiation in vitro (Zhang et al., 2010). The present study depicted a significant decrease in Hct and Hg by 5Gy $\gamma$-irradiation which indicates anaemia (Patil et al., 2000). This is attributed to the haemolysis of youngest red blood cells (Means, 1999) failure or decreased erythropoiesis (Nunia et al., 2007), destruction of mature cells, or increased plasma volume (Malhotra and Srivastava, 1978).

In the present study, significant reduction of WBC and its differential count was observed in irradiated group compared to the control. Depletion of lymphocytes is attributed to apoptosis, although necrotic death also occurs (Duvall and Wyllie, 1986). This is because lymphocytes and monocytes are non replicating cells that reside in blood for about one day before migrating into various tissues where they differentiate into macrophages that is relatively radio resistant (Sado et al., 1998). Neutrophils are non-mitotic that have a half-life of 10-12 h once they leave the bone marrow (Mollinedo et al., 1999). The kinetics of neutrophil release depends upon the form of radiation administered during first week after exposure (Kajioka et al., 2000).The significant drop in the bone marrow cells is attributed to irradiation induced bone marrow depression (Prasad, 1995). 
IL-2 is a cytokine released by $\mathrm{T}$ helper lymphocytes, that promotes its generation, proliferation, and differentiation, enhances the activity of natural killer cells, induces the generation of lymphokine-activated killer cells and promotes the production of antibodies by B lymphocytes (Gong, 2003). The present study demonstrated decreased IL-2 in irradiated animals which is attributed by Bass et al. (1989) to that spleen cells of total lymphoid (TLI) irradiated mice, secrete 5-9\% of the mean normal level of IL-2. Investigations show that $\mathrm{T}$ cells from TLI-treated mice produce more IL-4 and less IL-2 and IFN- $\gamma$ than normal counterparts (Field et al., 1997). $\gamma$-irradiation significantly inhibit the proliferation of effective $\mathrm{T}$ cells by reducing the levels of Th1 type cytokines (such as IL-2) (Han et al., 2005).

TNF- $\alpha$ is synthesized by monocytes, macrophages, natural killer cells, granular lymphocytes, and $\mathrm{T}$ lymphocytes. The present results showed that 5Gy $\gamma$-irradiation induced a significant decrease in TNF- $\alpha$, which Tsukimoto et al. (2009) attributed to the anti-inflammatory effects of $\gamma$-irradiation in cells of mouse macrophages cell line. TNF induced by irradiation could regulate the BM cells apoptosis which is a crucial event in BM dysfunction (Cachaço et al., 2010).

The present results showed significant reduction of GSH in parallel to elevation of MDA by irradiation which could be attributed to enhanced utilization of the antioxidant system in an attempt to detoxify radiation generated free radicals (Krishna and Kumar, 2005). Depletion of GSH may be partly attributed to inflammation (Meister, 1991). Excessive lipid peroxidation can increase GSH consumption (Manda and Bhatia, 2003).

Adaptive immunity is mediated by lymphocytes derived from bone marrow precursors, thymus and lymphoid tissue (Delves and Roitt, 2000). Haematopoietic stem cell transplantation (HSCT) is the best treatment for many primary immunodeficiencies (Bhattacharya et al., 2005). The present results discerned that BMT alone lead to a significant elevation in WBCs, RBCs and Hct\% as compared to the control group after 35 days which comes in accordance with Nunia et al. (2007). BMT post irradiation showed restoration of blood parameters. Increased Hct value has been also reported by Andrea et al. (1987) one week post 9Gy and BMT. Atkinson, (1990) mentioned an initial monocyte recovery accompanied by the emergence of circulating colony-forming progenitors, subsequently the neutrophil count rises to normal values by about 1 month post BMT.

Egypt. J. Rad. Sci. Applic., Vol. 25, No. 1-2 (2012) 
In the present study, BMT to irradiated animals induced no change of IL-2 compared to irradiated animals. Wang et al. (2002) explained that IL-2 concentrations in recipient mouse serum were low, because of cytokine autocrine and paracrine physiological characteristics. BMT could cause lack of IL-2 producing cells and/or increased activity of suppressor cells of the helper function. Also, serum level of soluble IL-2 receptor was increased in patients who developed acute graft-versus-host disease post allogeneic BMT and is significantly related to disease severity (Nakamura et al., 2004) which support successful engraftment of bone marrow.

Irradiated BMT rats had elevation of TNF- $\alpha$ compared to irradiated group, that may be related to absence of the immunological reaction against non-HLA allogeneic antigens. Shalaby et al. (1988) proved increased TNF in allogeneic mixed lymphocyte reaction. Neutralization of TNF- $\alpha$ have been reported by Brown and Thiele (2000) to reduce complications after BMT.

The present improvement of oxidative stress by irradiation followed by BMT, is explained by De Rooij et al. (2002) to rise in erythropoietic activity in bone marrow and spleen so that elevation of RBCs, as a source of GSH, ameliorate oxidative stress (Ashry and Hussein, 2007).

The innate immune system, uses numerous receptors, and cytokines, and can respond immediately (Zhang et al., 2010). The present results demonstrate the effective potential of IFN- $\alpha$ upon reconstitution of blood parameters, which are in agreement with Ashry et al. (2009). Haematopoietic cytokine use with BMT has been shown to hasten neutrophil recovery (Williams et al., 1996). Cytokines cause rapid and transient changes in the numbers of leukocyte subsets and play a key role in the regulation of peripheral blood cell traffic (Walter et al., 2005). It was shown that IFN- $\alpha$ after chemotherapy modulates immune responses by amplifying T-lymphocyte activation and enhancing natural killer cell activity (Tompkins, 1999). Early administration of IFN- $\alpha$ has demonstrated complete haematological response rates ranging between 40 and $80 \%$ (Kantarjian et al., 1995). The present elevation of IL-2, with IFN- $\alpha$ is attributed by Crossley et al. (1996) to increased natural killer cell activity with consistent increase in Th 1 activity and a decrease in autoantibody production.

The present results showed that administration of IFN- $\alpha$ after $\gamma$-irradiation normalized serum level of TNF- $\alpha$ post exposure to irradiation. This is attributed 
by Hill et al. (1997) to that the production of TNF- $\alpha$ by monocytes and macrophages is transuded by a priming signal that may be provided by interferon IFN- $\gamma$ and radiation. Kosar et al. (1999) showed also that TNF- $\alpha$ increase post-treatment with INF- $\alpha$ indicate the presence of immune system activation and endothelial injury/activation. TNF- $\alpha$ might be potentially applied as a therapeutic agent to enhance sensitivity to $\gamma$-irradiation in radiotherapy (Youn Yi et al., 2010).

The present results showed ameliorated GSH and MDA post irradiation and IFN- $\alpha$. This is attributed to IFN- $\alpha$ enhancement to biological defence activities against oxidative stress (Lu et al., 2002). Han et al. (2005) showed that IFN $\alpha$ improves the health status, as well as oxidative stress and resulted in a sustained lowering of serum lipid peroxidation, and increase of GSH concentration (Shohrati et al., 2010).

A broad range of cytokines can serve to accelerate bone marrow restoration following radiation, i.e. a significant innate response can trigger and augment adaptive immune responses (Miller and Neta, 1993). The present findings confirmed enhanced hematopoietic reconstitution, accelerated BM restoration and enhanced biological defence activities against oxidative stress by boosting adaptive and innate immunity. The present findings highlight new opportunities for irradiation patients using immunoregulatory factors enabling BMT.

\section{References}

Abedi, M., Greer, D. A., Colvin, G. A., Demers, D. A., Dooner, M. S., Harpel, J. A., Pimentel, J., Menon, M. K. and Quesenberry, P. J. (2004) Tissue injury in marrow transdifferentiation. Blood Cells Molec. Dis., 1, 32.

Andrea, C. W., Phyllis, H. L., Seiki, T. Julie, L. N. and Morris, I. O. (1987) Characterization of xenogenetic mouse-to rat bone marrow chimeras. Transplant, 44, 88.

Aramachi, T. (1989) Immuno-Biological Laboratories Company, Ltd. Japan. 370: 831.

Ashry, O. M. and Hussein, E. M. (2007) Radioprotective potency of ginsengon on some haematopoeitic and physiological parameters in irradiated rats. Egypt. J. Rad. Sci. Applic., 20, 365.

Ashry, O. M., Hussein, E. M. and Salama, S. F. (2009) Boosting of antioxidant defense by interferon-alpha in irradiated bone marrow transplantation rats. Egypt. J. Rad. Sci. Applic., 22, 19.

Atkinson, K. (1990) Chronic graft-verus-host disease review. Bone Marrow Transpl., $5,69$.

Egypt. J. Rad. Sci. Applic., Vol. 25, No. 1-2 (2012) 
Augustine, A. D., Gondre'-Lewis, T., McBride, W., Miller, L., Pellmarc, T. C. and Rockwelld, S. (2005) Animal Models for radiation injury, protection and therapy. Rad. Res., 164, 100.

Bass, H., Mossmann, T. and Strober, S. (1989) Evidence for mouse Th1- and Th2like helper T cells in vivo. J. Exp. Med., 170, 1495.

Beutler, E., Duron, O. and Kelly, B. (1963) Improved method for determination of blood glutathione. Lab. Clin. Med., 61, 5.

Bhattacharya, A., Slatter, M., Chapman, C., Barge, D., Jackson, A., Flood, T., Abinun, M., Cant, A. and Gennery, A. (2005) Cord blood stem cell-single centre experience of umbilical cord stem cell transplantation for primary immunodeficiency. Bone Marrow Tansplant., 36, 295.

Brown, G. R. and Thiele, D. L. (2000) Enhancement of MHC class I-stimulated alloresponses by TNF/TNF receptor (TNFR) 1 interactions and of MHC class II-stimulated alloresponses by TNF/TNFR2 interactions. Eur. J. Immunol., 30, 2900.

Cachaço, A. S., Carvalho, T., Santos, A. C., Igreja, C. and Fragoso R. (2010) TNF- $\alpha$ regulates the effects of irradiation in the mouse bone marrow microenvironment. Rad. Res., 5, 8980.

Carl, A. and Braun, C. (2005) Tietz Textbook of Clinical Chemistry and Molecular Biology. 2nd ed. Saunders Company, p. 566.

Chan, V. S. and Perlstein, L. D. (1987) Affinity chromatographic separation of alphafetoprotein variants. Academic Press, New York, p. 71.

Crossley, A. R., Dickinson, A. M., Proctor, S. J. and Calvert, J. E. (1996) Effects of interferon-alpha therapy on immune parameters in immune thrombocytopenic purpura. Immunol., 35, 423.

Dacie, S. T. and Lewis, S. M. (1993) Practical Haematology. ELBS and Churchill, Levingston. London Chapt. 5: 37.

De Rooij, D. G., Van de Kant, H. J., Dol, R., Wagemaker, G. and Van Buul, P. P. (2002) Long-term effects of irradiation before adulthood on reproductive function in the male Rhesus monkey. Biol. Reprod., 66, 486.

Decleave, A., Gerber, G. B., Leonard, M., Lambiet-Collier, M., Sassen, A. and Maisin, J. R. (1972) Regeneration of thymus, spleen and bone marrow in Xirradiated AKR mice. Rad. Res., 51, 318.

Delves, P. J. and Roitt, I. M. (2000) The immune system. New Engl. J. Med., 343, 37.

Duncan, D. (1957) Multiple range tests for correlated and hetroscedastic means. Biometrics, 13, 164.

Duvall, E. and Wyllie, A. H. (1986) Death of the cell. Immunol., 7, 115.

Esser, M. T., Bess, J. W., Suryanarayana, K., Chertova, E., Marti, D., Carrington, M., Arthur, L. O. and Lifson, J. D. (2001) Partial activation and induction of apoptosis in $\mathrm{CD}^{+}$and $\mathrm{CD} 8^{+} \mathrm{T}$ lymphocytes by conformationally authentic noninfectious human immunodeficiency virus type 1. J. Virol., 75, 1152. 
Field, E. H., Rouse, T. M., Gao, Q. and Chang, B. (1997) Association between enhanced Th2/Th1 cytokine profile and donor T-cell chimerism following total lymphoid irradiation. Hum. Immunol., 52, 144.

Gong, F. L. (2003) Medical Immunology. $1^{\text {st }}$ ed. Beijing, China Science ,Vol. 1: p. 238.

Han, S. K., Song, J. Y., Yun, Y. S., and Yi, S. Y. (2005) Gamma irradiation reduced IFN-gamma expression, STAT-1 signal, and cell-mediated immunity. $J$. Biochem. Mol. Biol., 35, 583.

Hill, G. R., Crawford, J. M., Cooke, K. J., Brinson, Y. S., Pan, L. and Ferrara, J. (1997) Total body irradiation and acute graft versus host disease: the role of gastrointestinal damage and inflammatory cytokines. Blood, 90, 3204.

Kantarjian, H. M., Smith, T. L. and O'Brien, S. (1995) Prolonged survival in chronic myelogenous leukemia after cytogenetic response to interferon alpha therapy. Ann. Int. Med., 122, 254.

Kosar, A., Haznedaroglu, S., Karaaslan, Y., Büyükasik, Y., Haznedaroglu, I. , Ozath, D., Sayinalp, N., Ozcebe, O., Kirazli, S. and Dündar, S. (1999) Effects of interferon- $\gamma 2$ a treatment on serum levels of tumor necrosis factoralpha, tumor necrosis factor-alpha2 receptor, inter.leukin-2, interleukin-2 receptor, and E-selectin in Behçet's disease. Rheumatol. Int., 19, 11.

Krishna, A. and Kumar, A. (2005) Evaluation of radioprotective effect of Rajira (Amaranthus paniculatus) extract in Swiss albino mice. Rad. Res., 46, 233.

Lu, G., Shimizu, I., Cui, X., Itonaga, M., Tamaki, K., Fukuno, H.,Inoue, H., Honda, H. and Ito, S. (2002) Interferon alpha enhances biological defense activities against oxidative stress in cultured rat hepatocytes and hepatic stellate cells. J. Med. Invest., 49, 172.

Malhotra, N. and Srivastava, P. N. (1978) Haematological effects after administration of radiophosphorus in mice. Radiobiol. Radiother., 19, 347.

Manda, K. and Bhatia, A. L. (2003) Preadministration of beta-carotene protects tissue glutathione and lipid peroxidation status following exposure to gamma radiation. Environ. Biol., 4, 369.

Maurya, D. K., Adhikari, S., Nair, C. K. and Devasagayam, P. A. (2007) DNA protective properties of vanillian against $\gamma$-radiation under different conditions possible mechanisms. Mat. Res., 7, 634.

Means, J. (1999) Neocytolysis from outer space to the dialysis unit. Am. J. Kidney Dis., 33, 140.

Meister, A. (1991) Glutathione deficiency produced by inhibition of its synthesis and its reversal. Pharmacol. Ther., 51, 155.

Miller, L and Neta, R. (1993) Therapeutic utility of cytokines in counteracting bone marrow suppression of radio- and chemo-therapy. In:Clinical Applications of Cytokines: Role in Pathogenesis, Diagnosis and Therapy (Gearing A, Rossio J,Oppenheim J, eds). New York: Oxford Univ. Press, p. 225.

Mollinedo, F., Borregaard, N. and Boxer, A. (1999) Novel trends in neutrophil structure, function and development. Immunol., 12, 535.

Egypt. J. Rad. Sci. Applic., Vol. 25, No. 1-2 (2012) 
Muriel, P., and Castro, V. (1997) Biliary obstruction in rats phamacology. J. Med. Invest., 54, 179.

Nakamura, T., Good, R., Yasumizu, R., Inoue, S., Oo, M. M., Mamashima, Y. and Ikehara, S. (2004) Successful liver llografts in mice by combination with allogenic bone marrow transplantation. J. Proc. Natl. Acad. Sci., 12, 4529.

Nunia, V., Sncheti, G. and Goyal, P. K. (2007) Protection of Swiss albino mice against whole-body gamma irradiation by diltiazem. Brit. J. Radiol., 80, 77.

Ortaldo, R. J. and McCoy, J. L. (1980) Protective effects of interferon in mice previously exposed to lethal irradiation. Rad. Res., 81, 262.

Peter, U., GottlÖber, P., Nadeshina, N., Krähn, G., Braun-Falco, O. and Plewig, G. (1999) Interferon gamma in survivors of the Chernobyl power plant accident: New therapeutic option for radiation induced fibrosis. Int. J. Rad. Onco. Biol., 1, 147.

Prasad, K. N. (1995) Radiation immunology. In: Handbook of radiobiology, 2nd ed, New York, CRC Press Inc. p. 193.

Sado, T., Kamisaku, H., Ikarashi, Y. and Kubo, E. (1998) Immediate and long-term effects of radiation on the immune system of specific-pathogen-free mice. Int. J. Radiat. Biol. Relat. Stud. Phys. Chem. Med., 53, 177.

Shalaby, M. R., Espevik, T., Rice, G. C., Ammann, A. J., Figari, I. S., Ranges, G. E. and Palladino, M. A. (1988) The involvement of human tumor necrosis factors- $\alpha$ and $\beta$ in the mixed lymphocyte reaction. J. Immunol., 141, 499.

Shohrati, M., Dermanaki, F., Babaei, F. and Moayed, S. (2010) Evaluation of the effects of oral $\mathrm{N}$-Acetylcysteine and a placebo in paraclinical and oxidative stress parameters of patients with chronic hepatitis B. Blood, 10, 95

Sinai, M. , Uma Devi, S. and Yadav, S. (1978) Radiation protection of bone marrow lymphocytes by 2-Mercaptoprpionylglycine (MPG). Rad. Res., 15, 1627.

Tompkins, W. A. (1999) Immunomodulation and therapeutic effects of the oral use of interferon-alpha: mechanism of action. J. Interferon Cytokine Res., 19, 817.

Tsukimoto, M., Homma, T., Mutou, Y. and Kojima, S. (2009) 0.5Gy gamma radiation suppresses production of TNF-alpha through up-regulation of MKP-1 in mouse macrophage RAW264.7 cells. Rad. Res., 17, 219.

Walter, E., Herbert, T., Wolfgang, V., Wolfgang, A., Manuela, B., Günther, G., Manfred, H. and Christoph, H. (2005) Acute hematologic effects of interferon alpha, interferon gamma, tumor necrosis factor alpha and Interleukin 2. Immunol., 8, 145.

Wang, Q., Jiang, J. Y. and Xie, S. S. (2002) Determination of doxycycline in serum by high-performance liquid chromatography. Chin. J. Clin. Phamacol., 3, 119.

Williams, S. F., Lee, W. J. and Bender, J. G. (1996) Selection and expansion of peripheral blood CD34+ cells in autologous stem cell transplantation for breast cancer. Blood, 87, 1687. 
Yoshioka, T., Kawada, K., Shimada, T. and Mori, M. (1979) Lipid peroxidation in maternal cord blood and protective mechanism against activated oxygen toxicity in blood. Am. J. Obstet. Gynecol., 135, 372.

Youn Yi, J., Jin Jang, Y., Shim Choi, S. and Chung, E. (2010) TNF-alpha down regulates E-cadherin and Sensitizes Response to $\gamma$-irradiation in Caco-2 Cells. Cancer Res. Treat., 41, 164.

Zhang, D., Cohn, L., Ray, P., Bottomly, K. and Ray, A. (2010) Transcription factor GATA-3 is differentially expressed in murine Th1 and Th2 cells and controls Th2-specific expression of the interleukin-5 gene. J. Biol. Chem., 272, 21597.

Received: 18/10/2012;

accepted: $29 / 11 / 2012$

Egypt. J. Rad. Sci. Applic., Vol. 25, No. 1-2 (2012) 
التعـافي المنـاعي في الجـرذان المعالجـة إثـعاعيا عقب عمليـة

زرع نخاع العظام والحقن بالإنترفيرون ألفعان

إلهام مصطفى حسين ، و ياسمين حسنين عبد النبي

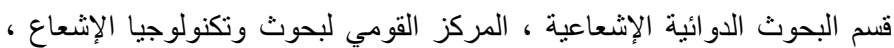

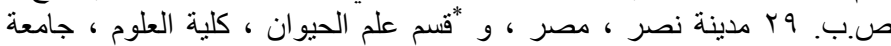

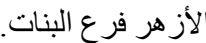

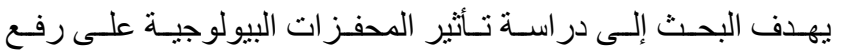

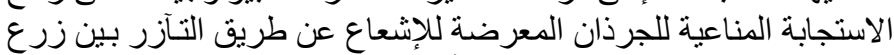

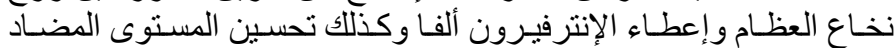

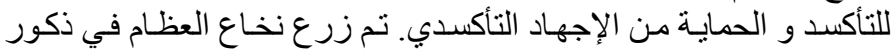

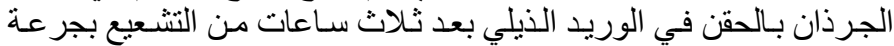

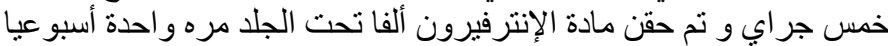

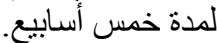

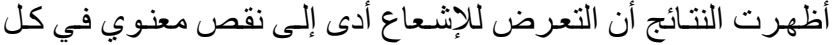

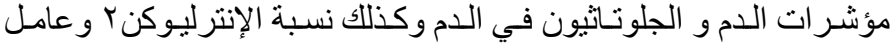

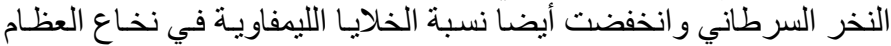

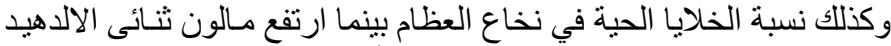

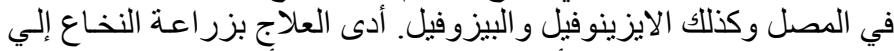

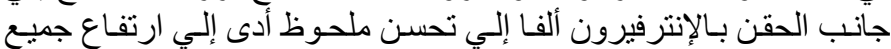

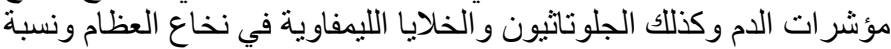

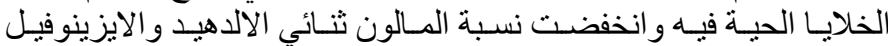

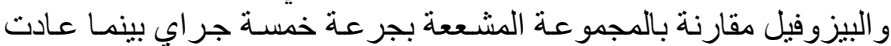
نسبة الإنترليوكن ب و عامل النخر السرطاني إلي نسبتهما الطبيعية.

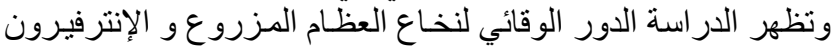

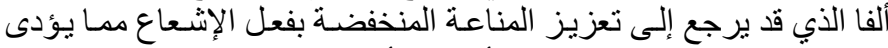
إلى تحفيز الدفاعات الطبيعية ضد أعباء التأكسد.

Egypt. J. Rad. Sci. Applic., Vol. 25, No. 1-2 (2012) 